\title{
SIX NAMES FOR THE END
}

\author{
Time to say goodbye.
}

\section{BY KEN HINCKLEY}

\section{LAST GASP}

The silver dollar clunks through the innards of the coin-box and out of the return with a hollow ring.

"What's wrong Daddy?" asks my daughter, Clematissa, from her faded stallion of handpainted plastic.

"Nothing, Tissa, don't worry about it," I reply, using the diminutive she accepts only from me.

In a fit of sentimentality I had named her after the extinct vines that once trellised the gardens of the world. Now, the pout furrowing her brow mocks the geometry of pink tulle (improvised by her mother, of course) that ruffles her dress.

"Then why won't the horsies go?"

The abandoned shopping centre reeks of stale air salted with dust, baked too many years under an oven of cracked skylights that turn the firmament into a shattered dream. Punctured soup cans and protein-jerky wrappers litter the carousel, but I thought maybe one last go-round on Tissa's favourite stallion would give her something to remember me by.

Guess not.

"I think they're just all tuckered out, sweetie," I say, as I roll up the sleeves of my work-jersey. "They need to rest up for the big trip too."

Her lower lip curls and her eyes brim with tears.

"Hang on a minute," I say, with a wink. I fix the leather strap around Tissa's waist. Then I jump down, grab one of the tarnished brass poles, and push. There's no music and the lights on the mirrors stare back at me like so many dead eyes, but at least the up-and-down of the horses accompanies my exertions.

I run round and round till I'm drenched in sweat, my jersey ripe with the fug of it. Out of shape, gasping for air.

"Thank you, Daddy," she says as I lift her off the stallion, and the look in her eyes almost melts my heart. "You smell awful!"

\section{QUIETUS}

I've read the last story and there she is, my little angel gone to sleep. Her chest rises and falls atop the mattress and I pull the fleece blanket, patterned with pink and purple hearts, over her tiny body.

It's the last thing I can do for her.

The apartment is quiet, too quiet. No hum of the fridge. No clink of a radiator warming up. I settle on the musty-smelling carpet next to Tissa.

It's gonna be a long, long night.

\section{TERMINUS}

Our marriage ended badly, this awkward union of Barbara and Wilbur, like so many other things on this world. Even our names sounded terrible together. It should have been a clue.

But at least I won partial custody. For a time.

Everyone's so busy getting ready to leave this place behind that they've forgotten their roots. Forgotten where they come from. It makes them light in the head, spending all their time in such rarefied air.

The Lagrange staging-points are bustling. The brilliant flares of the departing starships make an inferno of the sky, night after night after night.

I tell Tissa it's the dawn of new hope, even though I can't come round to believing it myself.

Because someone has to stay behind.

And someone always does.

\section{FINIS}

They say we can't long survive here. That soon there'll be nothing left to save. The world's done. Finito. Finis.

Well, colour me sceptical. Or just stubborn.

I intend to fight to the end.

But what ties me to this piece of rock? What is it really that makes me stay?

My father died here, and his father before him. I can taste the salt of the evaporating oceans on the air.

I imagine what's left is filled with tears. All the tears of every man, woman and child who ever lived. I can't let that dry up. I can't let that all be for nothing.

The oceans will brim again.

\section{SAYONARA}

I don't tell Tissa it's the last visit. I don't tell her it's the end. I don't even say goodbye.

I just drop her with the governess at the station. Kiss her on the cheek. Pretend it's just another time I'm sending her back to Mommy.
All this strength, this hard shell I put on, hides a weak man.

Sayonara to me.

\section{RAPTURE}

Tissa's mother comes down from the sky. The transport roars as it touches down, unsettling the earth, sending the dust off in a fruitless search of heaven. A stairway drops, a uniformed steward leads a line of children to the bottom, and they ascend, clutching plush dolls and security blankets to their cheeks.

I catch sight of Tissa as she hesitates near the top. She searches for me in the thin crowd, but I'm too far away, my wave too feeble and a moment too late to catch her attention.

She's gone.

My resolve wavers and suddenly I'm clomping down the aluminium bleachers, sprinting across the tarmac.

But I'm not running to her.

No, I'm putting as much distance between myself and the transport as my iffy knees will allow.

I've made my choice. I'm going to forge something of this broken-down Earth. It's where I belong.

But that doesn't mean I can bear to watch Tissa go.

I know she'll find her new home out there, in the stars, after I'm long dead. It's a lightspeed journey, or nearly so. My Tissa, my only daughter, is destined to live a million years.

And when she gets there, I like to think that she might even remember this one-trick pony she once called Daddy, that she'll look back on an Earth born anew.

But right now I can't get far enough away.

As I run, the transport accelerates past Mach 1, a pressure wave that fractures the sky.

It makes the sound of my heart breaking in two.

Ken Hinckley - writer, principal scientist (Microsoft Research) and editor-in-chief (Transactions on Computer-Human Interaction) - invents the future of sensors, mobility and multi-modal interaction. Follow: kenhinckley.wordpress.com 